\title{
Drought Coping Strategies and Their Effectiveness: The Case of Ward 12 in Mberengwa District Zimbabwe.
}

\author{
Sally Masendeke ${ }^{1} \&$ Kampion Shoko ${ }^{1}$ \\ ${ }^{1}$ Geography and Environmental Studies, Midlands State University, Zimbabwe \\ Correspondence: Kampion Shoko, Geography and Environmental Studies, Midlands State University, Private \\ Bag 9055, Gweru, Zimbabwe. Tel: 263-773-642-624. E-mail: kampion0054@ gmail.com
}

\author{
Received: February 19, 2013 Accepted: March 3, 2013 Available online: December 5, 2013 \\ doi:10.11114/ijsss.v2i1.299 URL: http://dx.doi.org/10.11114/ijsss.v2i1.299
}

\begin{abstract}
The study was carried out in Mberengwa Ward 12, which is characterised by erratic and inadequate rainfall. Drought frequency is very high occurring at a rate of four in every five years. The main purpose of this research was to establish the drought coping strategies that are in place and to establish their effectiveness. The data was collected from informants through questionnaires, group discussions and special interviews with key persons. Drought coping strategies which were identified included responses to production, consumption, food storage, income generating assets and livestock management. External assistance from the Government, NGOs and migration complimented these strategies. From the results it is recommended that there is need to develop effective coping mechanisms based on risk minimization such as utilisation of indigenous food sources and growing of drought tolerant crops not only in this ward but in other areas with similar environment and climate.
\end{abstract}

Keywords: coping strategy, drought, early warning systems, traditional varieties, response

\section{Definition of Terms}

Household - according to the Zimbabwe 1992 Census, a household was defined as people eating from the same pot, while councilors define a household as people staying at the same stand.

Coping strategies - short-term responses to an immediate and irregular decline in access to food (FAO, 1997) These strategies refer to people's activities whose main purpose is to meet their needs under conditions of extreme food scarcity and include making contingencies for the future. Coping strategies refer to a set of measures adopted to attempt to meet physiological, social, economic and political needs of every day life.

Traditional Varieties - refers to crop varieties selected and developed by farmers whether they originate in the survey communities or have been introduced from other communities (World Development journal number 26, 1993).

Early Warning Systems -refers to a range of systems for data collection, analysis and communication (Neefjes, 2000). This range goes from elementary, community based systems of observation and communication to highly sophisticated systems involving satellite observation and communication computer simulation and scores of specialists.

Drought - periods of increased dryness due to precipitation falling far short of expected of that expected for a region (Pickering \& Owen, 1994). Meteorologists define drought solely on the basis of the degree of dryness and the duration of the dry period whilst agriculturalists link drought to agricultural impacts focusing on precipitation shortages.

Indigenous knowledge - refers to knowledge of the local environment and how people try to put the world around them in some kind of order, some kind of system which is intended to assist in making decisions on appropriate ways of planning survival strategies ( Mararike, 1999).

\subsection{Introduction and Background}

Drought as a natural hazard has been ranked as number one in terms of increased frequency and intensity as compared to other hazards like floods and earthquakes. In 1960, about 18.5 million people were affected by drought worldwide and by the 1970s, this figure rose to 24.4 million (Swedish Red Cross Statistics, 1984). 
According to the United Nations, Food Agricultural Organization report in 1984, 150 million people in Southern Africa were affected by the 198213 drought. According to Agazzi (2013), drought affects more people than any other natural disaster: since 1900 more than 11 million people have died as a consequence of drought, and over two billion people have been affected. In Africa, a third of the people already live in drought-affected areas.

Agazzi (2013) further states that half of the world population will live in areas of high water scarcity by 2020. And drought is the single most common cause of food shortages, severely affecting food security in developing countries and jeopardising FAO's effort to increase food production by 70 percent by 2050 in order to feed a world population of 9 billion.

The worst drought in the region was experienced a decade later in the 199112 season. Past occurrences of drought have been linked to certain events such as El Nino and volcanic eruptions. Though droughts are normal and regular climatic events in Southern Africa, human activities have also increase the frequency and severity of droughts through deforestation and overgrazing. Drought periods are therefore very unpredictable and people should plan their cropping and other activities accordingly as mismanagement of one drought leads to reduced productivity and greater susceptibility to the next drought.

The SADC Regional Early Warning Unit, the Regional Remote Sensing Project, the Drought monitoring centre and the Famine Early Warning System Project all advice governments on drought preparedness. Although weather information is available in the region, the challenge is to ensure that weather information such as forecasts are translated into management decisions if crises are to be avoided. Current coping strategies are however biased towards short-term solutions such as food handouts, food for work projects and supplementary feeding schemes. Such interventions may immediately improve the material conditions of life in the existing drought situation but do not empower households to fend for themselves in future droughts. Farmers faced with drought are therefore expected to make better use of the little water that would be available in order to minimize the effects of drought and to take advantage of more plentiful rainfall when it comes.

\subsection{Drought Coping Strategies}

FAO (1997) noted that communities that have lived under drought situations for many generations develop coping strategies to lessen the impact of drought. Recently, people in southern Africa have developed effective responses to alleviate the ravages of drought on their communities. These indigenous responses go a long way in alleviating food shortages caused by droughts.

\subsubsection{Households' Own Coping Strategies}

Communities that have lived under drought situations for many generations develop coping strategies to lessen the impact of drought. These strategies usually follow a sequence such as the reduction in the number of meals followed by migration and the sale of assets such as livestock (FAO, 1997).

\subsubsection{Production Response}

Hulme (1984), discuses the diversified traditional crop varieties adopted by peasant farmers in western Sudan in an attempt to cope with increasing persistent droughts. This is a means of spreading risks of total crop failure, because if one crop fails the other one will survive. Ruttenberg (1980), in a study of farming systems in the Tropics also noted that diversification of production such as growing a range of crops is a typical risk-spreading device used world over. The chief defense against food scarcity in Zimbabwe is the cultivator's skill whereby the staple crops such as millet (rukweza) and rapoko and bulrush millet (mhunga) are planted (Lliffe, 1980). These crops provide the best risk spread as they suit the low-rainfall areas. This observation is also a true reflection of what happens in Mberengwa district. Manzungu et al (1999) recommended short, medium and long season sorghum varieties which reduce the risk of complete crop failure. Dupriez ( 1988), also suggested that mixing many seed varieties of the same plant species can reduce the risk of crop failure because some varieties are early and others are late matures and they react differently to drought. According to Jerie and Matanga (2012), a variety of ethno-science based drought coping strategies are utilized in the southern part of Mberengwa district in Zimbabwe. These drought coping strategies include multiple cropping, early planting, planting drought tolerant crops, basin tillage, transhumance movement, supplementary feeding, destocking, deep welling, barter trade, selling/hiring labour and begging. Barter trade was the most widely practiced. In coping with drought using drought tolerant crops, households aim for survival of at least one crop, which can see them through to the next harvest.

\subsubsection{Income Response}

The way out for the poor in a drought prone area is the development of non-farm rural activities, which help to boost the income and thus enable households to fend for themselves. The World Development Journal No 26 
(1993) also discusses the income generation strategy adopted by rural households in times of droughts. These activities range from gardening to craft production. Harrison (1997) noted that dry season gardening projects such as those in Niger launched by the Lutheran World Services are also a vital drought coping strategy. In Southern Niassa, Mozambique, many individual farmers depend on piece work and in some households, young men have left to find work in occupations such as construction and they send money back to their families ( Neefjes, 2000). During the 1982-84 drought many rural households in Southern Zimbabwe generated income by harvesting, shelling and selling wild marula nuts, a species found in several countries in the region ( Chenje, 1994). Studies carried out by UNEP in 2002; reveal that the Hausa, of Northern Nigeria, in drought years resort to craft production, which they sell to generate income to buy grain to fend for the households.

\subsubsection{Migration Response}

When people's abilities to acquire food are outstretched by drought and local resources can no longer support the people, members move out to other areas to source for food or other means of accessing food. Wijkman and Timberlake (1984) note that many of the coping mechanisms of the Nomadic herdmen depend on movement to other areas after they have exhausted all other possibilities. Sen (1981), studying Sahelian droughts also noted that pastoralists migrated down south in quite large numbers as a way of reducing the impact of drought. Members are sent out of the home area to seek temporary and permanent employment. The majority of these migrations however involve men whilst acute situations involve women and children.

\subsubsection{Consumption Response}

People change their consumption patterns prior to drought situations. These strategies usually follow a sequence, starting with reduction in the number of meals eaten followed by increased consumption of wild and famine foods such as leaves, berries and rodents. Labour migration and the selling of bigger assets such as livestock and fields are the last resorts (FAO, 1997). According to Chenje (1994) rural people in Botswana utilize over 250 species of wild plants and animals during times of drought. About 119 different indigenous vegetable types and 36 mushrooms were identified as important food resources during drought years in Uzumba-Maramba- Pfungwe, Murewa, Chiredzi, Tsholotsho and Nyanga by the Community Technology Development Trust (CTDT) (Murimi/Umlimi Vol 5 no 3, May, 1999). UNEP carrying out studies of coping with drought in Northern Nigeria noted that the Hausa use wild foods as substitutes and a project conducted for the Africa Centre for Technology Studies in Kenya also revealed the use of indigenous plants in responding to droughts. Women have also developed their own ways of food preservation in order to store food long enough to bridge the dry season deficit (UNEP, 2002). FAO (1997) noted that in Mantapala, Zambia, nearly all households preserve some local vegetation at the end of the rainy season between February and May to overcome seasonal shortages. According to Chenje (1994), the Batswana have also developed food preservation and storage methods to establish and maintain a reliable, nutritious food base during long running droughts. The methods include sun drying, salting, parching and fermenting foodstuffs. In Ethiopia, successive stages of coping are taken that is consumption decline to reduced consumption per meal and reduced number of meals per day (Valdes, 1981).

\subsubsection{Asset Response}

Assets play a greater role in coping with drought as they can be converted to cash in order to buy food in during drought years. Carr (1997) asserts that in most cases when farmers are deprived of food by drought, they are forced to sell their livestock and then their meager household goods. Smaller assets like chicken are sold first, and if conditions continue to worsen, bigger assets like livestock, ploughs and fields are also sold. Lliffe (1990), studying droughts in Zimbabwe from 1890 -1960, noted that in drought years, cattle would be traded or even slaughtered for food. This idea is also supported by UNEP (2002) which stated that, under drought conditions, households may resort to selling livestock in order to buy grain.

\subsubsection{Indigenous Weather Forecasting Indicators Response}

Indigenous weather forecasting methods have also been employed as a drought coping strategy in Mberengwa district in Zimbabwe. This is supported by Shoko (2012) and Shoko (2013) in studies of the indigenous weather forecasting methods in wards 12 and 13 of Mberengwa. The study revealed that the residents of these wards rely heavily on weather forecasting indicators such as bird behaviour and celestial bodies to make adept decisions to reduce the severity of drought impacts. The rural community of Ilocos Norte Province of the Philippines use indigenous weather forecasts to plan and prepare agro forestry activities and also in disaster prevention. Using their indigenous weather forecasts, farmers prepare their upland farmlands in time to ensure that vegetative cover is established before the heavy rainfall season. This helps to prevent soil erosion during the heavy rainfall and enhances agricultural production (Galacga \& Balisakan, 2009). 


\subsubsection{External Assistance to Household Coping Strategies}

The government of Zimbabwe assists vulnerable households to cope with food deficit induced by droughts. Such assistance range from public works projects, supplementary feeding schemes, food aid and food for work. NGOS and social organizations are an important external assistance source for house hold drought coping strategies.

FAO (1997) highlights the idea of community storage for food security in Burkina Faso. The government assisted the community to create cereal banks at village level. These are small banks that are managed by small farmers themselves. They purchase the cereal immediately after harvest; store and sell back to villagers at lowest possible prices in times of shortage. This can help to improve households coping strategies as they can supply grain in dry periods (FAO, 1997). The idea is to bring back community involvement in food storage and supply. The Zunde RaMambo in Zimbabwe is based on the same concept.

\subsection{Objectives}

The main aim of this research was to identify household drought coping strategies and access their effectiveness for ward 12 of Mberengwa district in Zimbabwe. The objectives of this research were as follows:

- To identify drought coping strategies being used in Ward 12.

- To assess the effectiveness of the household drought coping strategies.

- To assess the effectiveness of government intervention and Zunde RaMambo as a drought coping strategies.

\subsection{Significance of the Study}

World- wide, people have tried various strategies to cope with drought. On the other hand not all of these strategies are effective and some of the coping strategies are yet to identified and documented. The current study is significant in that, it identifies and documents the drought coping strategies in this ward. The study goes on to assess the effectiveness of these coping strategies. This information and the recommendations will go a long way in designing sustainable drought coping strategies in this area.

\subsection{Area of Study}

Mberengwa is a district in Zimbabwe situated $180 \mathrm{~km}$ south of Gweru and $24 \mathrm{~km}$ southwest of Zvishavane in Natural Farming Region IV. The majority of the people in this area depend wholly on farming for their survival. Farming in this area is however affected by rainfall variability. Rainfall in this area ranges from $400-600 \mathrm{~mm}$ /year and the season length is only about 111 days. Droughts are very common in this area and it has been noted that there are usually 4 moderately dry years in 5 years, which means there is only one good season in 5 years. Mid-season droughts are also very common .Intra-season dry spells occur without fail even in good years and the average is about 10-20 days mainly in January. The district is divided into two electoral constituencies, East and West. Studies were carried in Mberengwa West. The district is further divided into 33 wards for administrative purposes including ward 12 where the villagers, who took part in the research, were located. The ward has got six villages and the population is about 5987 people (CSO, 1992). There are 948 households in the ward.

\section{Methods and Materials}

\subsection{Research Design}

The research adopted the case study approach. Data was collected from primary and secondary sources. Primary data was obtained from the households in the ward, community leaders, extension officers and councillors. Secondary data sources remained important. The library supplied information on the information about the study area. The councilor provided information on the population of the area and ward demarcation.

\subsection{Sampling Methodology}

A list of households was obtained from the Councillor. Random sampling was used to select $10 \%$ of the households in the six villages. Every tenth household was selected from the list and as a result 95 households were directly involved in the research. A sample size of $10 \%$ was necessary to attain the objectives outlined in the research. Random sampling helped to eliminate bias and was necessary to deal with a large population and obtain a representation of different variables from different people on a wider scale.

\subsection{Primary Data Sources}

A number of field surveys were used to solicit information on household drought coping strategies. Contemporary techniques included questionnaires, interviews, participatory rural appraisals and observations.

\subsubsection{Participatory Rural Appraisal (PRA)}

PRA consists of a tool kit of techniques presumed to enable researchers in the research process to share 
experiences and learn from each other. Transect walks across the study were made in the company of six local informants selected for their knowledge of the area by the head men. Two informants were selected from the six villages based on their age and experiences. Older members who have most of the information about the environment were not comfortable with such walks. They would rather give information in the comfort of a tree -shade in their compounds. The do-tell -me- what- you know approach was adopted to solicit information about households' experiences in past droughts and changes in food security. The experiences from PRA were that, it is necessary to understand villagers' shared and private modes of thought and the influences of their responses.

\subsubsection{Informal Group Discussions}

Participants to informal group discussions were usually village headmen; people who were known to experience food shortages when they attended food aid related meetings. These discussions were not pre-planned. A meeting with the chief with his headmen, whose ages ranged from 60 to 80 years, enabled the soliciting of information on issues such as indigenous knowledge and environmental indicators. The aim was to learn from their experiences. Information on consumption response and production response was obtained through this method.

\subsubsection{Key Informant Interviews}

The key informants in the ward included the councillor, extension officer, project leaders, community elders, and the chief and head men. Elders provided information on past drought experiences and indigenous knowledge systems that assisted in predicting drought years. Twelve elders were interviewed, two from each village. They were selected randomly using the drop and pick sampling method. There is only one extension officer in the ward, and he provided information on the traditional crop varieties found in the area and information on how through the AREX Department, they would encourage households to react to dry spells. The councillor provided information on the number of vulnerable households participating in public works projects. The Chief provided information on the Zunde Ra Mambo concept and the indigenous vegetables and plants found in the area. These interviews were carried out on one-to-one basis allowing an in-depth analysis of the subject.

\subsubsection{Observations}

Direct observations helped to gain insights into households' drought coping strategies. The study was carried out during the planting season to enable the identification of the crops grown, the planting times and diversification.

\subsubsection{Focus Group Discussions (FGD)}

Focus group discussions were held with participants from ward 12. Respondents came from all the 6 villages and these FGD were held at Chidembeko Business center because of its centrality. FGD usually started at 0900 in the morning. Groups were divided into males and females. Information on consumption, income, and asset response was obtained through this method.

\subsubsection{Questionnaires}

The basic approach that suited the magnitude of the research problem was the use of questionnaires. These helped to provide quantitative information such as family size, average number of cattle owned, land ownership and percentage of people $\backslash$ households adopting a particular technique as a coping mechanism. Questionnaires helped the researcher to get information that suited the demands of objective numbers two to five that focus on effectiveness of coping mechanisms. This also helped to increase 'objectivity' because when people give information in a group, some may be unduly persuaded to go along with the opinion of the influential members within the group, even if on their own, they would have thought differently. 100 household heads were selected from the ward out of 948 households. This was a laborious task that involved translation of some of the questionnaires into vernacular for the respondents to understand.

\subsection{Secondary Data Sources}

Secondary sources of data were also used to elicit information. The library was used to obtain background information, information on the study area's climatic characteristics and also for literature review. Newspapers and magazines also supplied good up to date information. Records kept by community leaders, extension officers and councilor were made use of to provide information relating to household drought coping strategies, number of vulnerable households and asset ownership. The Internet was also another source of data that was collected.

\subsection{Data Analysis Methods}

Both qualitative and quantitative methods of data analysis were used in this research. Interviews and PRAs provided qualitative form of data based on experiences and responses during drought periods. Experiences were seen from different perspectives and thus in the end, comparisons and contrasts were made. Quantitative data from the questionnaires was analysed using percentages. Simple tabulations and comparisons were also used. 
Tabular analysis began with the construction of a system of classification for example continuous variables such as age of household head were used. Bar graphs and pie charts were also used to present the results.

\section{Results}

\subsection{Demographic Characteristics}

Demographic characteristics of the sample population studied were, ages, head of household, family size, livestock ownership and asset ownership. These variables were essential in the discussion of the results.

\subsubsection{Ages of Respondents}

Figure 1 shows the age ranges of people who took part in the research.

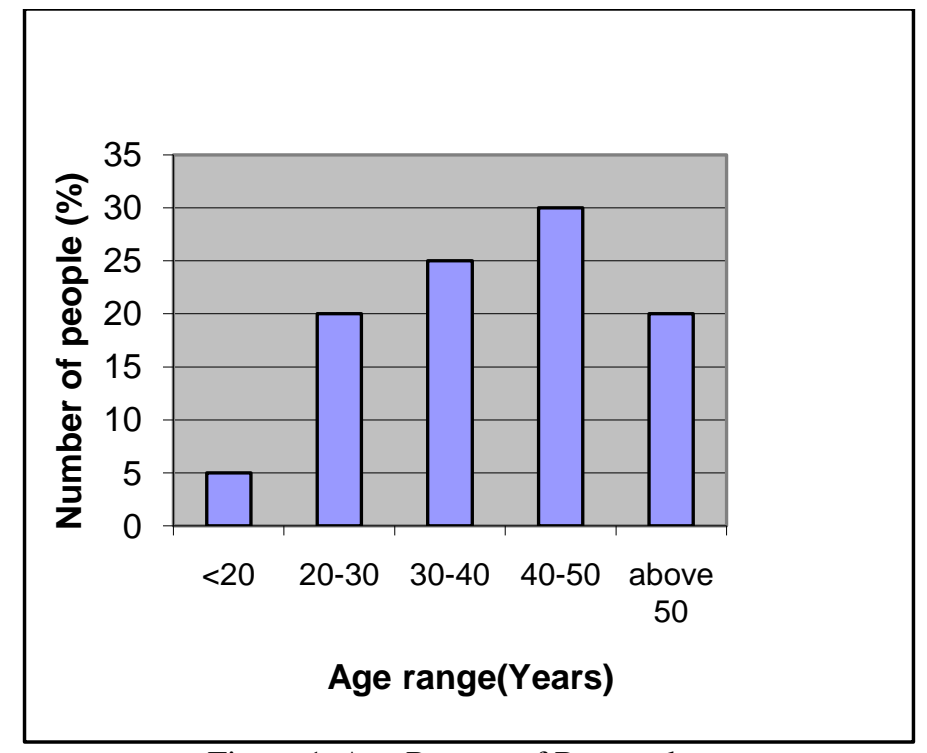

Figure 1. Age Ranges of Respondents

Figure 1 shows that $30 \%$ of the respondents were in the age range of $40-50$, and $25 \%$ in the $30-40$ age range. $20 \%$ were above 50, and another $20 \%$ between 20 and 30 and 5\% were below 20. These age ranges are important because they can determine the mode and type of the drought coping strategy.

\subsubsection{Head of Household}

Figure 2 shows the percentages of female-headed, child-headed and male-headed families.

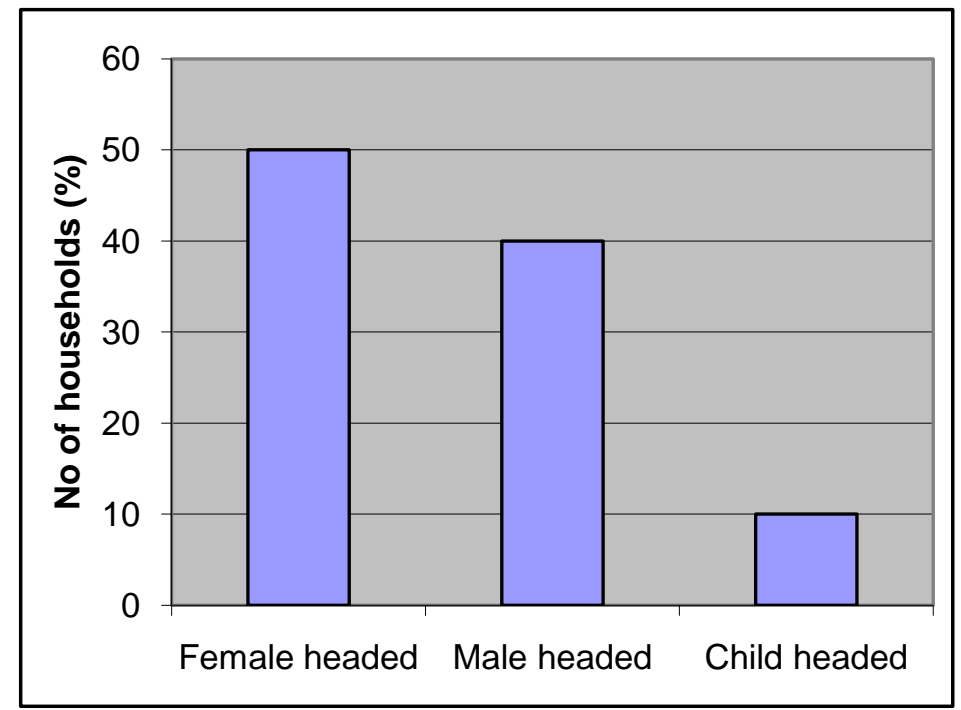

Figure 2. Percentage of female, male and child headed families

Figure 2 shows that $50 \%$ of the households are female-headed while $40 \%$ are male headed and $10 \%$ are child headed. So the sample comprised of mostly male and female headed households and very few child headed families. 


\subsubsection{Livestock Ownership}

Cattle constitute a major symbol of wealth for the households in ward 12 and the average number of cattle was found to be 6. Survey results reveal that households with cattle above 6 have more arable land, did early planting and achieved higher crop yields. Donkeys also make up the majority of livestock in ward 12. Small livestock like goats are also important in ward 12 as they survive better during droughts.

\subsubsection{Asset ownership}

The average farmland for the respondents was found to be 4 hectares. Those with basic farm implements cope better with droughts than those without. Figure 3 shows the percentages of households with basic farm implements.

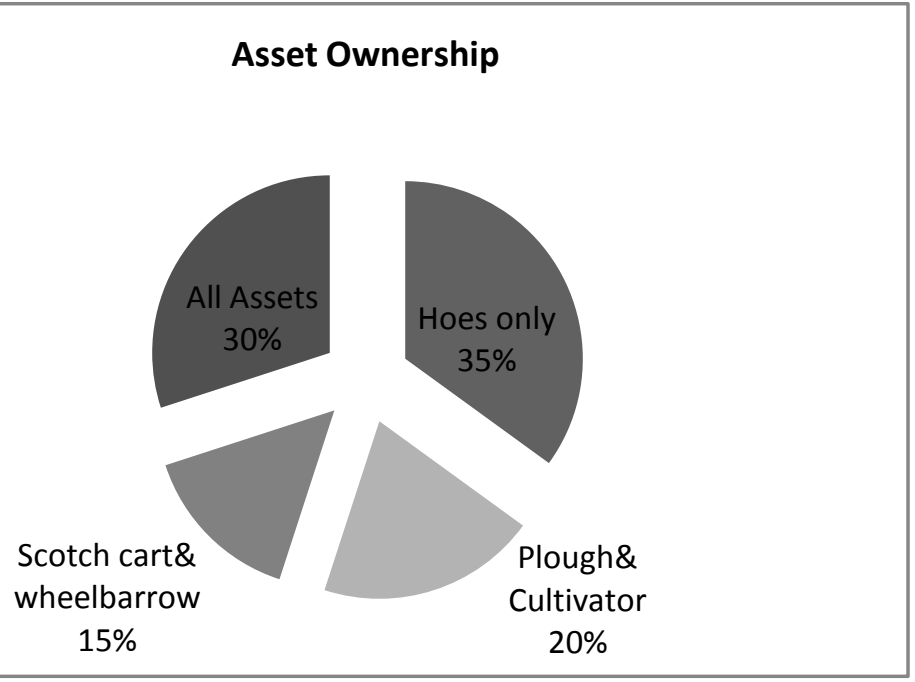

Figure 3. Asset Ownership

The majority (35\%) of the households has only hoes as assets, and $20 \%$ have ploughs and cultivators while $15 \%$ have scotch carts and wheelbarrows as assets. The percentage of those with all assets was $30 \%$. This percentage of households is found to be better able to cope with droughts because they are able to produce more from the fields.

\subsection{Households' Own Coping Strategies}

Survey results reveal that households in ward 12 adopt a number of strategies in order to cope with the increasingly persistent droughts. Participants of the group discussion were asked to rank the coping strategies according to their effectiveness and importance in coping with drought. Table 1 shows some of the techniques adopted by households in drought years:

Table 1. Household Drought Coping Strategies In Ward 12

\begin{tabular}{lc}
\hline \multicolumn{1}{c}{ Technique } & Rank \\
\hline Supplement diet with wild food & 1 \\
Plant drought tolerant crops & 2 \\
Diversify income base & 3 \\
Migrate to other areas & 4 \\
Sell assets like ploughs & 5 \\
\hline
\end{tabular}

The strategy of supplementing diet with wild fruits and plants was ranked as the highest followed by planting drought tolerant crops. The third rank is diversifying the income base and the fourth rank is migrating to other areas while the sale of assets is the last in the rank. Supplementing the diet appears to be the most widely adopted technique and is effective in coping with droughts because most of the wild vegetables and fruits are drought tolerant and therefore would be available to bridge the dry season deficit.

\subsubsection{Production Response}

About $87 \%$ of the people in the study area almost wholly depend on farming for their survival. Farming in this area is affected by rainfall variability and as such people have now realized the need to plant traditional crops suitable to the area. The range of crops, which could be grown in this area, is given in Table 2. 
Table 2. Crops and Varieties Grown In Ward 12

\begin{tabular}{ll}
\hline Crop Type & Seed Variety \\
\hline Maize(Chibage) & SC 401 \\
& SC407 \\
& Pannar variety 473 \\
\hline Sorghum(Mapfunde) & Macia \\
& Sosoti \\
& Chizharawanya \\
\hline Bulrush millet(rukweza) & Chikwayi \\
& Garindi \\
\hline Millet (Mhunga) & Chimbewama \\
& Mwiseweshoko \\
& Mutsemuka \\
\hline Cowpeas(nyemba) & Ndaguta \\
& Kenya \\
\hline Roundnuts (Nyimo) & Chigogoba \\
& Chimugabe \\
& Jekenyekwa \\
\hline Sweet potatoes(Mbambaira) & Nyumwana \\
& Gunguo \\
& Damba \\
& Misiriridzi yemhebwe \\
& Usandidenha \\
& Chikavhu \\
& Kwava \\
& Dhumbe \\
\hline
\end{tabular}

The traditional crops and seed varieties circulate within the locality and the people have knowledge of how to preserve the seeds for future planting. These traditional crops and varieties do well in this area and are drought tolerant. Sorghum and bulrush millet are important crops as they can be used as an income generating strategy through beer brewing. Cowpeas are used to prepare 'mutakura' a nutritious meal comprising of a mixture of maize seed and cow peas which is usually used to supplement lunch.

Survey results revealed that maize was by far the most popular crop grown in the area.

Participants of the focus group discussion were asked to rank maize varieties according to their importance and the following results were obtained.

Table 3. The Maize Varieties Grown According To Their Importance

\begin{tabular}{ll}
\hline Maize Variety & Rank \\
\hline SC403 & 1 \\
SC 407 & 2 \\
SC401 & 3 \\
AC 31 & 4 \\
PANNAR VARIETY 473 & 5 \\
\hline
\end{tabular}

The people have knowledge of the suitable maize varieties to be grown in the area. SC 403 appears to be the most popular in ward 12 and the people know it by its code name 'chishoko'. This variety is drought tolerant and also matures early. SC 401 and SC 407 are some of the most important varieties. AC31 and Pannar variety 473 have been ranked third and fourth respectively. Rapoko, millet, groundnuts and sorghum are some of the crops, which are grown in the area. Women in most cases know the different planting times suitable for each crop type. Traditional crops and seeds circulate within the locality and the people have a wealth of knowledge on how to preserve the seeds for future planting.

\subsubsection{Farming Practices in Ward 12}

Research results reveal that the residents of ward 12 have adjusted their farming practices in order to cope better with drought. Figure 4 shows the farming practices adopted by households in Ward 12 in an attempt to cope with the increasingly persistent droughts. 


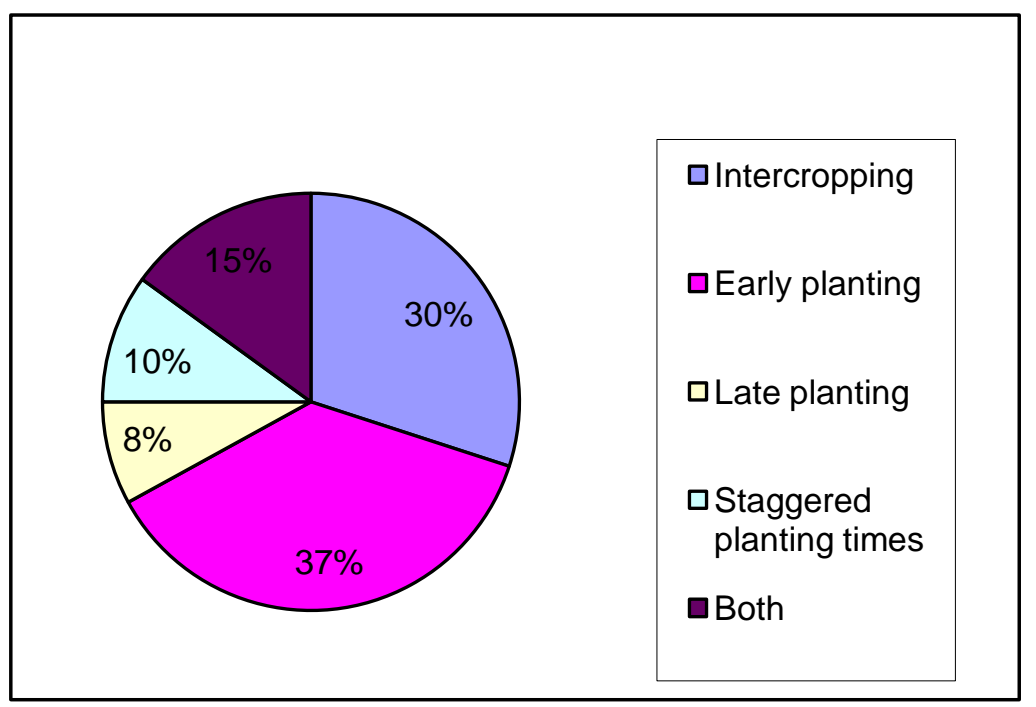

Figure 4. Farming Practices in Ward 12

Intercropping and early planting are best practiced in this ward with $30 \%$ of the households intercropping crops such as maize with cowpeas. $37 \%$ of the households plant their fields early. Land is ploughed early as soon as harvesting is complete and kept weed free to conserve moisture. Planting usually starts in mid-September to early October as soon as the first rains have moistened the soil. This is because the people are not sure whether the first crops will survive or not and they are trying to cope with the dry spell which usually comes in January. Early planting is usually on early maturing maize varieties such as SC401, AC 31 and SC 407 and cowpea variety (ChiMugabe). 1-2 fields are planted and planting continues until December.

$8 \%$ of the households plant late as a coping strategy. Late planting is done for early maturing varieties. Late planting is well practiced in Ward 12 because there is a tendency of letting cattle going astray as soon as the first crops have been harvested. Late planting is therefore usually done on a very small portion around the homesteads. $10 \%$ of the respondents stagger their planting dates so that if one crop fails the other one will survive. Survey results however reveal that those that have enough assets are able to stagger their planting dates. Female headed and child headed families cannot adopt some of these techniques because of labour constraints. What they practice most is intercropping. Cowpeas are intercropped with maize and rapoko to boost soil fertility and at the same time provide a good protein supplement.

\subsubsection{Consumption Response}

In order to cope with drought households in ward 12 change their main consumption patterns. Figure 5 shows the main consumption changes adopted by households in ward 12 prior to drought situations.

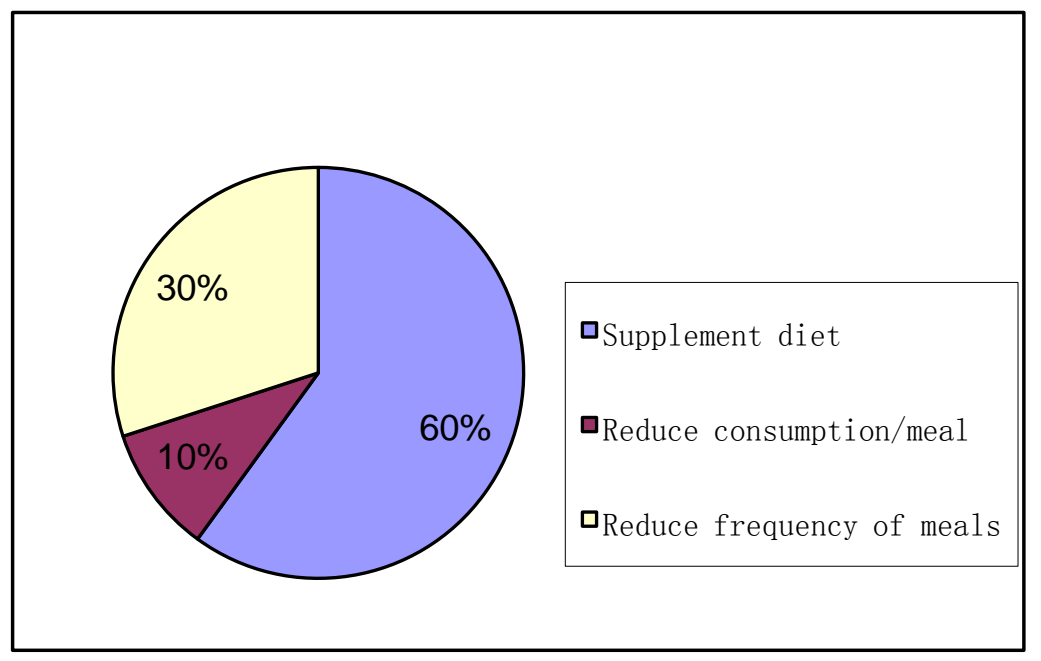

Figure 5. Consumption Changes Prior To Drought Situations 
Results from figure 5 reveal that prior to drought situations, $60 \%$ of the households supplement their diet with wild fruits and plants. Lunch is usually supplemented with wild fruits and plants taking note that drought period usually coincide with plenty of wild fruits. $30 \%$ of the households reduce the frequency and number of meals while $10 \%$ reduce consumption per meal. Table 4 shows some of the common wild fruits found to be important food substitutes in dry years in ward 12.

Table 4. Common Wild Fruits Consumed In Ward 12

\begin{tabular}{llll}
\hline Botanic name & Shona & Ndebele & English \\
\hline Azanza gackeana & Matohwe & Uxakuxaku & Snot apple \\
Berchemia discolor & Nyii & Umnyi & Bird plum \\
Vapaca kirkiana & Mazhanje & amahobohobo & $*$ \\
O. Puntia & Madhorofiya & Idorofia & Prickly pear \\
Sclerocarya birea & Mapfura & Umganu & Marula \\
\hline
\end{tabular}

The research showed that the prickly pear and marula are important food substitutes during drought years. Marula fruits are picked, shelled and fermented to make amarula drink and the seed cracked to extract the nuts that are eaten raw or ground to powder to make a source for relish.

Wild plants are also important elements in food security during periodic droughts in Ward 12 of Mberengwa district. Different indigenous vegetable plant types and mushrooms were also identified as important food resources in this ward. Table 5 shows some of the common wild vegetable types found to be important food substitutes in the ward.

Table 5. Common Wild Vegetables Consumed in the Area

\begin{tabular}{llll}
\hline Botanical name & Shona & Ndebele & English \\
\hline Cynadropsis gynandra & Nyevhe & Lude & Ulude \\
Amaranthus thunbergii & Mowa & Imbuya & Pigweed \\
Datura stramonium & Chowa/howa & Amakhowa & Mushroom \\
Seratotheca semanoids & Bupwe & Umdelele & Okra \\
\hline
\end{tabular}

Women's knowledge of the leafy vegetables was far superior to that of men. Participants of the group discussion were asked to rank different vegetable types according to their importance. Table 6 shows the ranking of selected vegetable types by the households.

Table 6. The Ranking of Selected Vegetable Types

\begin{tabular}{cc}
\hline Wild Vegetable Type & Rank \\
\hline Nyevhe & 1 \\
Derere & 2 \\
Imbuya & 3 \\
\hline
\end{tabular}

Nyevhe is more popular among households and was ranked the highest followed by derere and lastly imbuya. There is no technology on how to cultivate these crops because most of these grow wild in the fields. Some vegetable types are intercropped with major crops such as maize and sorghum while seeds are harvested, dried and kept in bottles for 2-3 years to come without losing their nutritional value. Popular indigenous mushrooms are found in miombo forests under the msasa (brachystegia spiciformis), minhondo (julbernadia globiflora) and muzhanje trees (vapaca kirkiana). Women have a wealth of knowledge of how to cook them with home made peanut butter.

\subsubsection{Food Preservation}

The people in Ward 12 have developed their own preservation methods as a drought coping mechanism. Indigenous vegetables and mushrooms that appear in the rainy season are preserved and stored for future use especially in drought years when exotic varieties like rape and cabbages do not do well. Vegetables are boiled before they are dried in the sun. These vegetables include cowpea leaves, cabbages, covo, rape and nyeve. Some mushroom types are thoroughly boiled with a bit of salt and then sun dried. These dried vegetables and mushrooms are kept in sacks and can be used in drought years. The households with dried vegetables and mushrooms are better able to cope with drought than those without because they need only grain to be able make a meal of sadza and relish.

\subsubsection{Migration Response}

In this ward people usually migrate to other areas when the drought situation is prolonged. Survey results reveal that most of these migrations involve men whilst acute situations involve women and children. Figure 6 shows the nature of migrations that take place during drought years in ward 12. 


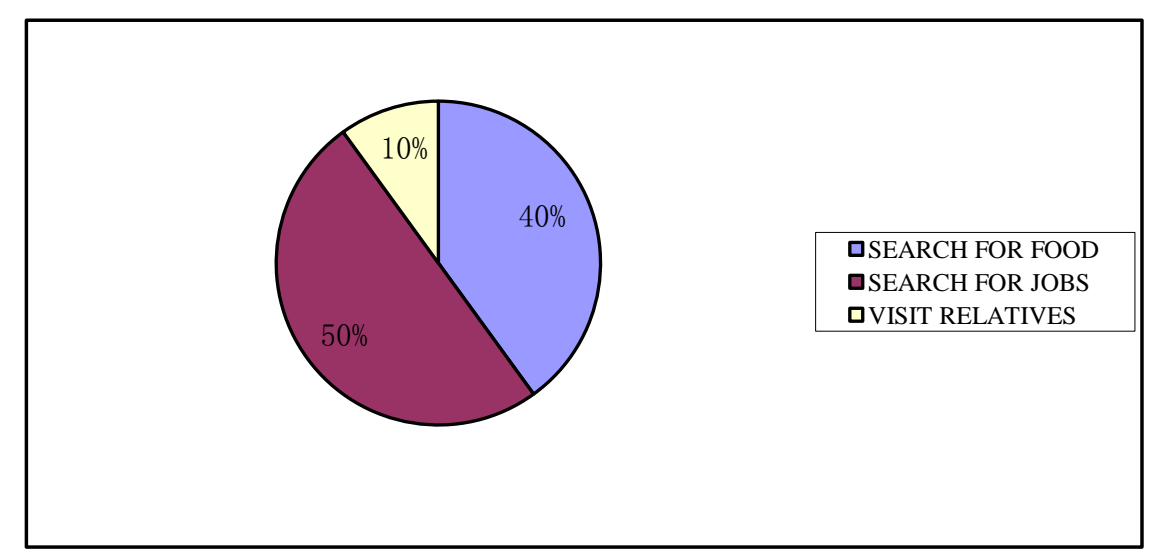

Figure 6. Nature of Migrations Prior to Drought Situations

Questionnaire results revealed that the majority of these migrations take place within the male-headed families involving males going into towns and cities to search for jobs. Thus $50 \%$ of these migrations are for job searching while $40 \%$ of the migrations involve women going into neighbouring areas such as Zvishavane in search of food. $10 \%$ of the migrations involve mostly child headed families visiting relatives in other areas so as to run away from the drought situation and return when conditions improve.

\subsubsection{Income Response}

Prior to drought situations people in ward 12 increase their income maintenance strategies in order to cope better with drought. During an informal discussion held, residents were asked to rank the income generating projects according to their importance in coping with drought years. These are shown in table 7.

Table 7. Income Generating Projects in Ward 12

\begin{tabular}{ll}
\hline Project & Rank \\
\hline Gold panning & 1 \\
Gardening & 2 \\
Selling labour (maricho) & 3 \\
Selling farm produces & 4 \\
Selling homebrewed beer & 5 \\
Selling assets & 6 \\
\hline
\end{tabular}

Gold panning was ranked 1 as a drought coping strategy. Gold panning involves mostly men whilst gardening projects are second in the rank and involve mostly women. Households usually retire from the fields when the drought situation is prolonged and concentrate on gardening. Income is generated through the sale of tomatoes, cabbages and carrots. These gardening projects are funded by the Lutheran Development Services. Some of the gardens are Sikovha, Matinginde, Magacha and Biri Group gardens. Markets for the produce are shown in Fig 7.

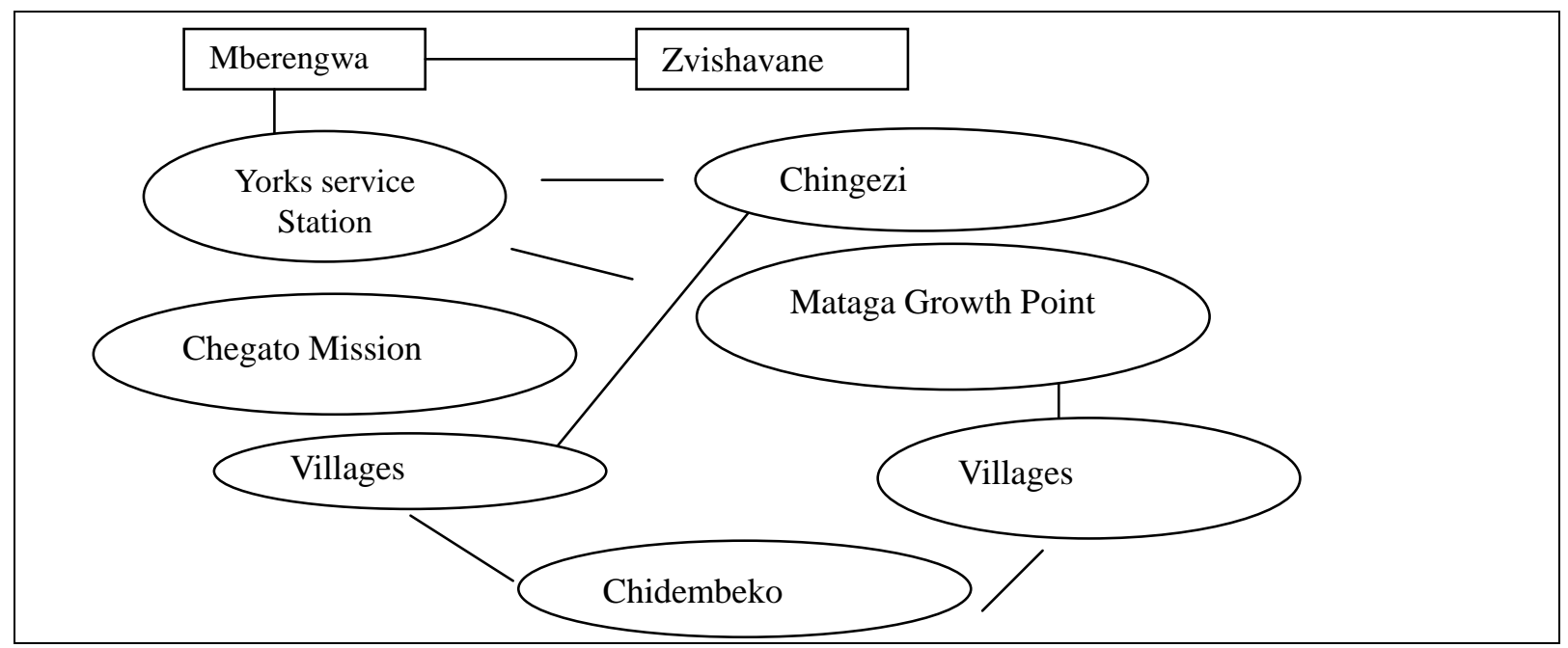

Figure 7. Vegetable Markets for the Villagers 
Sometimes the market is flooded with the produce such that prices drop. As a result the income generated from such sales may be too little to cater for the family. Another problem with the marketing of produce concerns the transportation of the produce to areas such as Chegato mission and Mataga growth point. Transport is not readily available and some villagers have to use scotchcarts and donkeys to ferry the produce. Survey results reveal that about $21 \%$ of the people in the study area are in formal employment. Some work in different urban centers in the country and others are employed and operate within the area as teachers or relief agents. These are able to send money to their families to buy a wide range of commodities needed for survival. 'Maricho' or selling labour was ranked the third. This could involve herding cattle, weeding, threshing and building houses in exchange for money or grain from those not affected by the drought. The majority of those who sell labour are young families and child headed families. The survey also revealed that the income generated from selling farm produce represents a small portion of the activities the villagers engage in to generate income during drought. This is because droughts, pests and diseases affect rural produce. The sale of assets was ranked the last because most of the households do not have enough assets to dispose off.

\subsubsection{Asset Response}

Survey results reveal that metal ploughs and hoes are the widely used farm implements in ward 12. Assets are usually disposed off in ward 12 by some households when the drought situation is prolonged. Smaller assets are however sold first such as hoes and smaller livestock like goats and chicken. The selling of assets involves mostly the poor because they sell the assets in desperation and as a result become more vulnerable to the next drought situation. Those with more than four cattle usually select the old cattle and sell them. The money obtained from such sales is used to buy grain. Those with few assets usually find it difficult to cope with drought since they have very little or nothing to sell.

\subsubsection{Livestock Management}

In spite of a wide range of charismatic uses, the provision of meat, milk and draught power explain cattle's dominance in ward 12. Frequent droughts are however dampening the spirit of most small-scale cattle producers. Households adopt different strategies in order to cope better with drought. Figure 8 shows some of the strategies adopted by households in managing their livestock in drought years.

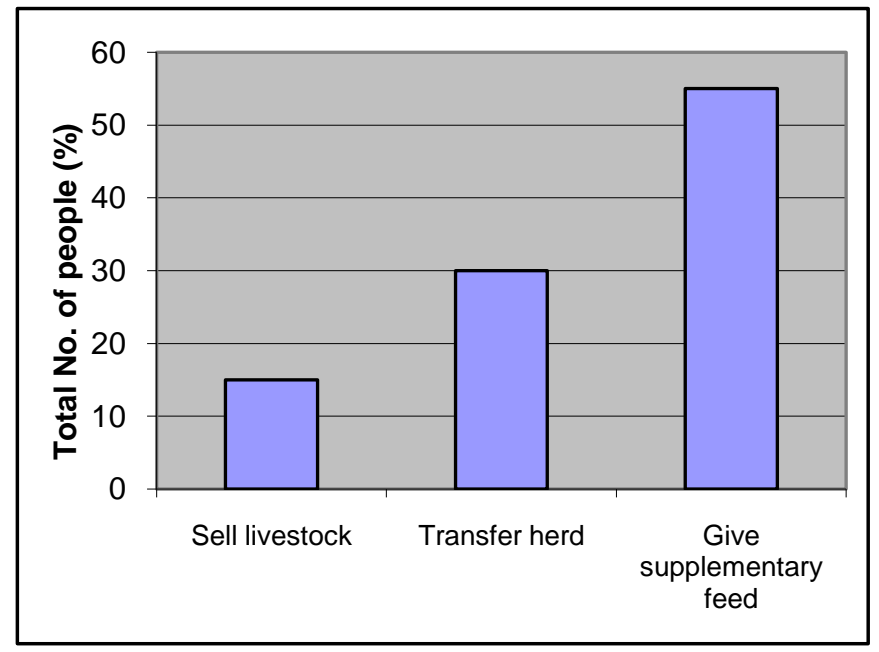

Figure 8. Livestock Management in Times of Droughts

$55 \%$ of the households keep supplementary feed such as maize stover, grass and groundnut hay obtained in good years to be used in drought years. $30 \%$ of the households transfer their herd to other areas where grass will be plenty such as York's farm and Costas ranch. 15\% of the households sell their livestock in desperation. Survey results reveal that the majority of the households have diversified livestock comprised of cattle, goats and donkeys. In most cases donkeys and goats survive the drought situation better than cattle.

\subsection{External Assistance}

External assistance to household drought coping strategies in Ward 12 comes from the Government and is in form of Public Works Projects (PWP) and Zunde Ra Mambo and fro Non Governmental Organizations (NGOS) like Lutheran World federation and CARE international. 


\subsubsection{Government Public Works Projects}

In the year 2003, 829 households participated in Public Works Projects (PWP) and were given \$5000 (Zimbabwean Dollars) after every three weeks. (Councillor's records) Taking into consideration the fact that a bucket of maize was being bought at $\$ 20,000$ (Zimbabwean Dollars) the cash was too little to fend for the households. The selection criterion was that people with no regular income and food stocks should participate in such projects. Households who seem to benefit more as revealed by the questionnaires are the poorer who have a less diversified income base, which means that income from PWP represents a larger share of total household earned income. Female headed and child headed families also benefit more from these. Those headed by males would rather seek other means of generating income. Poor targeting and screening excludes a large number of food insecure households. The frequency of PWP payouts needs to be increased from the initial three months interval.

\subsubsection{Zunde RaMambo Concept}

Zunde RaMambo acts as a security to drought in ward 12. However, very few people benefit from it as revealed by the questionnaire responses. Zunde RaMambo had long disappeared over the years only to resurface in 2002 after a parliamental discussion. The chief is responsible for its administration and receives inputs from the government through the Grain marketing board. Land is allocated to two head men in the ward that is Gwandiwa and Chikopero. These head men in turn organise their own kraal heads for the preparation of the land through to harvesting. There is active participation of the community. The produce is stored in a grain reserve (dura) only to be distributed by the chief to affected households during times of droughts. The problems faced in the implementation of Zunde RaMambo emanated from delayed inputs and poor organization of the community. Kraal heads fail to organize their own people and this renders Zunde RaMambo ineffective.

\section{Discussion of Results}

The results have established that the residents of ward 12 in Mberengwa district of Zimbabwe employ a number of drought coping strategies. These drought coping strategies include production response, farming response, consumption response, food preservation techniques, migration response, diversification of means of livelihood, asset response and livestock management response. The residents also receive assistance from the government through the Public Works Projects, Non Governmental Organisations (NGOS) and the community's Zunde ra Mambo.

The production response is widely used as a drought coping strategy and it involves the growing of drought tolerant maize varieties and small grains as shown in table 2. This result concurs with Hulme (1984) and Ruttenberg (1980) who established that diversification of traditional crop varieties and the farmers' skill for opting for small grains to minimise risks is an important drought coping strategy. Ward 12 is located in the semi-arid region of Zimbabwe, where rainfall is unreliable and inadequate. So the growing of small grains and drought tolerant maize cultivars is a viable coping strategy for drought. The residents of ward 12 have also adopted farming practices that reduce the severity of drought. Intercropping and early planting are some of the most practiced farming methods in coping with drought in this ward. The growing season usually has inadequate rainfall and ends prematurely. So, intercropping and early planting enable the residents to at least reap something under these circumstances.

Ward 12 residents respond to drought situations by changing their consumption patterns to cope with food shortages in drought years. 60\% supplement their diet with wild fruits and plants, while $30 \%$ reduce the number of meals they have per day. This concurs with FAO (1997)'s assertion that in drought situations, people change their consumption patterns. The consumption related coping strategies start with reductions of meals eaten per day, followed by an increased consumption of wild and famine foods such as leaves, berries and rodents. Food preservation methods have also been practised to alleviate the adverse effects of drought in the ward. Indigenous vegetables and mushrooms are preserved and stored for future use especially in drought years. This concurs with Chenge (1994), who established that the Batswana use wild plants and animals during times of drought. The utilisation of indigenous dried vegetables is also in line with UNEP (2002)'s assertion that women develop their own ways of food preservation in order to store food long enough to bridge the dry season deficits.

The other drought coping strategy cited by the residents was migration. In this ward migration was basically for food procurement, job procurement and visiting relatives who are able to feed them for the period they will be visiting. 50\% migration was for job opportunities and $40 \%$ was for food procurement. Most of these migrations involved men while women stayed in the homes looking after the children. Sen(1981), studying the Sahelian drought established similar trends of migration. 
Household assets are also used to cope with drought as they can be easily converted to cash in order to buy food during drought years. Survey results revealed that assets are usually disposed of by the heads households when the drought situation is prolonged. Smaller assets such as hoes followed by smaller livestock such as chickens and goats are also sold while larger livestock such as cattle are the last to be sold and only the oldest beasts usually are disposed of. These findings are supported by Car (1997) who argued that in most cases when farmers are deprived of food by drought, they are forced to sell their livestock and their meagre household goods. This practice is further more supported by UNEP (2002) which stated under drought conditions, households may resort to selling livestock in order to buy grain.

Another coping strategy for drought cited by the residents was livestock management. 55\% of the respondents keep supplementary feed such as maize stover, grass and ground nut hay for use during drought years while 30\% said they transfer their herd to other areas where pastures are better. The households have also a diversified livestock such as cattle, goats and donkeys. Donkeys and goats survive better in drought years. Donkeys are particularly used as draught power during periods of drought.

Zunde RaMambo acts as a form of food security for the residents in the ward. However, very few people benefit from its meagre food reserves. The effectiveness of Zunde RaMambo is compromised by delayed, and at times by the unavailability of inputs. This situation is made worse by the failure of kraal heads to organise their own people to work in the Zunde RaMambo plots. The findings also indicated that the effectiveness of Non Governmental Organisations is sometimes compromised by inadequate financial resources and by political interference.

Responses from questionnaires and from participatory rural appraisals revealed that Indigenous weather forecasting methods are also employed as drought coping strategies in Mberengwa district in Zimbabwe. This is supported by Shoko (2012) and Shoko \&Shoko (2013) in their studies of the indigenous weather forecasting methods in wards 12 and 13 of Mberengwa. The studies revealed that the residents of these wards rely heavily on biotic and abiotic weather forecasting indicators to make adept decisions to reduce the severity of drought impacts.

\subsection{Conclusion}

The study sought to investigate the household drought coping strategies for Ward 12 of Mberengwa District and to assess their effectiveness as coping mechanisms.

The study established that household drought coping strategies go a long way in mitigating the impact and severity of droughts. From the results of the study it can be concluded that the capacity for coping with drought is a function of the asset base, income distribution, and the capacity to cope with production in good years. Those households with a firm asset base manage to attain high production out of the land and thus cope better with drought situations. The relative contribution of indigenous knowledge and early warning systems is vital and should not be overlooked. The utilization of indigenous foods has played a significant role in food insecure regions and continues to play an important role even in the area covered by this study. Improved preservation and drying of foods also ensures that people do not run out of stock during the dry period. Most households are now aware of the agronomic practices to be adopted in their area and as a result they make efficient use of every drop of rain that falls through early planting and staggered planting dates. In most cases they have something to fall back on. The re-emergence of Zunde RaMambo is important in order to bring back community involvement in food storage and supply. The concept of food for work played a pivotal role in curbing the dependency syndrome and also in facilitating development in this rural area.

\subsection{Recommendations}

In view of the above conclusions, the following recommendations can be made to various stakeholders:

\section{(i) The Government}

- should not focus on crisis management but on risk avoidance in order to help households cope better with drought and thus Zunde RaMambo should be enhanced through effective and timely distribution of inputs.

- should aim to improve the inputs of the peasant resource base through credit facilities to purchase inputs, expansion of crop and livestock extension services and offering of better producer prices so the farmer can aim to produce more.

- should invest in educating, training and increasing literacy among the peasants so as to enhance the capabilities of the poor. Educated farmers appear more eager to adopt new techniques of production and respond to drought situations positively. 
- should effectively ensure that weather information is translated into management decisions for example budgeting for relief and through institutional preparedness. Response measures should be combined with monitoring of preventive measures. Government should ensure that seasonal forecasts are disseminated and explained to farmers and advice on the types of crops to grow.

(ii)Non-governmental Organisations

- should complement their coping mechanisms with those of households for example

through improved research of the utilization of indigenous foods and in return educate the households on their preservation and importance in poverty alleviation.

(iii)Communities affected by droughts

- should deter from depending on the government or NGOs for drought relief but should build up their confidence in utilizing indigenous foods within their vicinity.

- should aim to accumulate assets in good years through food storage and investments in valuable disposable goods such as jewelry and farm equipment. These can be sold in drought years.

- should make effective use of Iks and EWS as important coping mechanisms

- communities should manage their production with risk minimization principles in mind for example early planting or staggered planting dates.

(iv) Research Centres

- should make use of the traditional crop varieties found in low rainfall areas to develop hybrid seeds.

In this era where droughts have increased in their intensity and frequency, there is need for communities to develop effective coping mechanisms based on risk minimization rather than crisis management. Communities can make it if they boost their confidence in the utilization of indigenous foods within their vicinity and should make use of indigenous knowledge systems and early warning systems as important drought coping mechanisms.

\section{Acknowledgement}

We would like to express our sincere gratitude to all the residents of the area for their willingness to help and supply the information used in this study.

\section{References}

Abbort, J. (Eds.). (1993). Agriculture and food marketing in LDCs. Cab International, UK.

Agazzi, I. (2013). Drought hits policies. Retrieved from http://www.ipsnews.net/2013/03/drought-hits-policies/

Braun, J. (1995). Employment for poverty reduction and food security. International Food Policy Research Institute.

Carr, M. (1997). New patterns: Process and change in human geography. Thomas Nelson and Sons Ltd, UK.

Dupriez, H. (1988). Agriculture in African rural communities. Macmillan, USA.

FAO. (1997). Agriculture, food and nutrition for Africa. FAO Publishing Management Group, Rome.

Galacgac, E., \& Balisakan, C. (2009). Traditional weather forecasting for sustainable agro forestry practices in Illocos Norte Province Philippines. Forest Ecology and Management, 257(10), 2044-2053. http://dx.doi.org/10.1016/j.foreco.2009.01.002

Harrison, P. (1987). The greening of Africa. Paladin Grafton Books, UK.

Hulme, M. (1984). An exceptionally dry year in central Sudan. Oxford University Press, UK.

Iliffe, J. (1990). Famine in Zimbabwe 1890-1960. Mambo Press, Gweru, Zimbabwe.

Jerie, S., \& Matanga, E. (2011). The effectiveness of ethno-science based strategies in drought mitigation in Mberengwa district of southern Zimbabwe. Journal of Sustainable Development in Africa, 13(4), 395-409.

Manzungu, E.A., Senzane \& Van der Zaag, P. (1999) (Eds.). Water for agriculture in Zimbabwe: policy and management options for small holder sector. University of Zimbabwe Publication.

Mararike, C.G. (1999). Survival strategies in rural Zimbabwe. Mond Books, Zimbabwe.

Neefjes, K. (2000). Environments and livelihoods, strategies for sustainability. Oxfam Publication.

Pickering, K.T., \& Owen, L.A. (1994). An introduction to global environmental issues. London, UK. 
Ruttenberg, H. (1980). Farming systems in the tropics. ( $3^{\text {rd }}$ Eds.). Calerondon Press, UK.

Sen, A. (1981). Poverty and Famines, An essay on entitlement and deprivation, Oxford

Shoko, K. \& Shoko, N. (2013). Indigenous weather forecasting systems: A case study of the abiotic weather forecasting indicators for wards 12 and 13 in Mberengwa district Zimbabwe, Asian Social Science, 9(5), 285- 297

Shoko, K. (2012). Indigenous weather forecasting systems: A case study of the biotic weather forecasting indicators for wards 12 and 13 in Mberengwa district Zimbabwe, Journal of Sustainable Development, 14(2), 92- 114

UNEP. (2002). Africa environment outlook, past present and future Perspectives, Earthprint Ltd, UK

Valdies, A. (Ed) (1981). Food security for LDCs, A westview special study, Westview Press, London

Wijkman, A., \& Timberlake, L. (1984). Natural disasters, acts of God or man? An Earthscan Paperback, London.

World development journal number 26, (January 1993) Pergamon Press, UK.

ZFU. (1999). Murimi/Umlimi.5(3), May, 1999. ZFU Publications University Press, UK.

\section{(c) $)$ EY}

This work is licensed under a Creative Commons Attribution 3.0 License. 